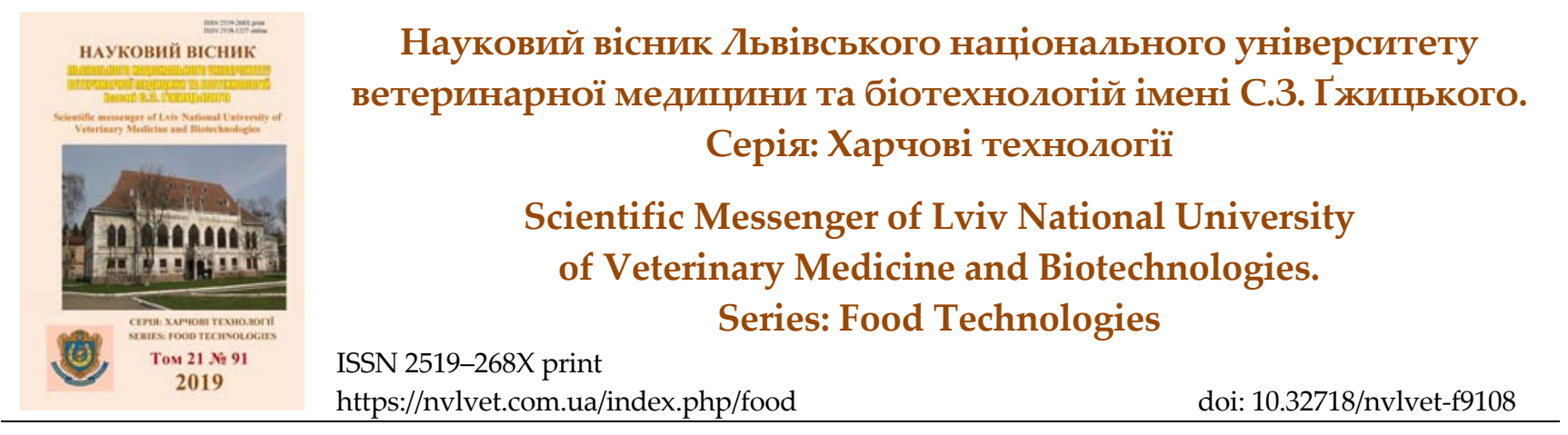

UDC 637.5

\title{
Pasteurized sausages with high heme iron content
}

\author{
T. Khorunzha, V. Pasichnyi, A. Marynin, R. Svyatnenko, O. Moroz \\ National University of Food Technologies, Kyiv, Ukraine
}

Article info

Received 18.01.2019

Received in revised form 15.02 .2019

Accepted 18.02.2019

National University of Food Technologies,

Volodymyrska Str., 68

Kyiv, 01033, Ukraine.

Tel.: +38 (044) 289-95-55

E-mail:pasww1@ukr.net
Khorunzha, T., Pasichnyi, V., Marynin, A., Svyatnenko, R., \& Moroz, O. (2019). Pasteurized sausages with high heme iron content. Scientific Messenger of Lviv National University of Veterinary Medicine and Biotechnologies. Series: Food Technologies, 21(91), 43-47. doi: $10.32718 /$ nvlvet-f9108

Current issue of today is the process of increasing the range of sausages and extending their storage time, especially for a boiled group of sausages. Therefore, the subject of research is pasteurized sausage, with an increased content of heme iron. The aim of the work was to create a complete product with high organoleptic characteristics, balanced according to biological and nutritional value and to select optimal thermal regimes to increase the shelf life of the product and to preserve the nutritional properties of the product, since cooked sausages have a limited shelf life, and due to properly selected heat regimes, we reach our goals. The receipts of sausages, based on meat of chicken-broiler using dry milk serum, collagencontaining preparation Scan-Pro, based on skin of pigs and micronized food cellulose with a definite level of hydration, a fat-based emulsion on the basis of chicken skins and a collagen-containing preparation Scan Pro and food blood. To increase the content of heme iron towards boiled sausages, food blood of pigs was added, in addition to increasing the nutritional and biological value of blood has a colorforming effect, with its introduction in an optimal amount, to achieve a characteristic color of sausage products. Sauce with the use of jelly-forming thickeners based on food hydrocolloids was added as a sauce. The value of the buffer capacity of the jelly after pasteurization was investigated. The basis for the production of pasteurized sausages was the technology of boiled sausages followed by heat treatment by pasteurization in order to provide an extended shelf life. Sausages were pasteurized at different temperature regimes. To determine the biological value of developed sausages, it was used the application program BIO1.bas. The chemical composition of sausages was modeled based on their functional and technological parameters. Physicochemical, microbiological, organoleptic research of the product was carried out. The amino acid composition of the product was simulated, which allowed to mention upon the biological and nutritional value of the studied formulations.

Key words: sausages, fiber, fats, protein-fat emulsion, heme iron.

\section{Сосиски пастеризовані з підвищеним вмістом гемового заліза}

\author{
Т.О. Хорунжа, В.М. Пасічний, А.І. Маринін, Р.С. Святненко, О. Мороз \\ Національний університет харчових технологій, м. Київ, Украӥна
}

\begin{abstract}
Актуальним питанням сьогодення є збільшення асортименту ковбасних виробів та подовження терміну їх зберігання, особливо для вареної групи ковбасних виробів. Тому предметом досліджень є сосиски пастеризовані, з підвищеним вмістом гемового заліза. Метою було створення повноцінного продукту з високими органолептичними показниками, збалансованими за біологічною $і$ харчовою ичінністю та підібрати оптимальні теплові режими для збільшення терміну зберігання продукту та збереження поживних властивостей продукту, оскільки варені сосиски мають обмежений термін зберігання, та за рахунок правильно підібраних теплових режимів ми досягаємо поставленої мети. Розроблено рецептури сосисок на основі м'яса курчат-бройлерів з використанням сухої молочної сироватки, колагеновмісного препарату на основі шкури свиней Скан Про і мікронізованої харчової иелюлози з визначеним рівнем гідратачї, жирової емульсії на основі курячої шкури і колагеновмісного препарату Скан Про та харчовоі крові. Для підвищення вмісту гемового заліза до варених сосисок додавали кров харчову свинячу, крім підвищення харчової $і$ біологічної иінності кров має кольороформучу дію, при введенні ї̈ в оптимальній кількості, для досягнення характерного кольору ковбасних виробів. Як соуси застосовували соус з використанням желе-утворюючих згущувачів на основі харчових гідро колоїдів. Дослі-
\end{abstract}


джено значення буферної ємності желе після пастеризації За основу для виробництва пастеризованих сосисок була використана технологія сосисок варених з подальшим тепловим оброблянням шляхом пастеризації для забезпечення подовженого терміну зберігання. Сосиски пастеризували при різних температурних режимах. Для визначення біологічної цінності розроблених сосисок за допомогою прикладної програми BIOl.bas було змодельовано хімічний склад сосисок з урахуванням їх функиіональнотехнологічних показників. Проведено фізико-хімічні, мікробіологічні, органолептичні дослідження продукту, змодельовано амінокислотний склад продукту, щуо дозволило нам говорити про біологічну і харчову повночінність досліджуваних рецептур.

Ключові слова: сосиски, клітковина, жири, білково-жирова емульсія, гемове залізо.

\section{Вступ}

Традиційні варені ковбасні вироби мають обмежений термін зберігання і вимагають особливих умов зберігання на відміну від м'ясних пастеризованих сосисок, які завдяки проведеній пастеризації мають набагато довший термін реалізації (Howe et al., 2006; Ivanov et al., 2014). В сучасних технологіях пакування набуває поширення новий клас виробів традиційного асортименту, який завдяки використанню фізичних методів впливу на сировину, підвищеним вимогам до організації санітарної безпечності виробництв дозволяє виробляти продукцію подовженого терміну зберігання (Wood et al., 2008; Khorunzha et al., 2017).

Об'єктом досліджень є варені ковбасні вироби подовженого терміну зберігання. Метою $є$ розробка модельних рецептур сосисок пастеризованих, дослідження фізико-хімічних, мікробіологічних, органолептичних показників.

При належному підборі рецептурних збагачувачів, цільовому використанню суміжних продуктів, що отримують при виробництві м'яса, в поєднанні з біологічними збагачувачами тваринного походження можливо розробляти нові повноцінні ковбасні вироби цільового призначення (Pasichnyy et al., 2004; Lee, 2011). Важливим є також підвищення рівня збалансованості не тільки білкового, а й жирнокислотного складу (Nawar, 1996; Griffith \& Kaltashov, 2003).

В останні десятиліття у світі все більше уваги приділяється збільшенню ресурсів харчового білка, удо- сконалення техніки і технології переробки традиційних і нетрадиційних сировинних ресурсів у галузях харчової промисловості, розширенню асортименту повноцінних продуктів харчування в різному ціновому діапазоні (Cravens, 1981; Fayvishevskiy, 2006).

Сучасні методи аналізу, знання хімії харчової сировини і фізіологічних потреб людини дозволяють розробляти повноцінні м'ясні продукти, збалансовані за комплексом макропоказників (білків, жирів і вуглеводів) та мікроелементів, згідно 3 накопиченими знаннями науки про харчування при використанні композиційних сумішей (Nohr \& Biesalski, 2007).

У виробництві м'ясопродуктів значна увага приділяється використанню білкових поліпшувачів - продуктів переробки молока і яєць і купажованих сумішей на їх основі.

Також у варені ковбаси, консерви, комбіновані продукти додають пігменти крові. Поряд із фарбувальними властивостями крові не можна нехтувати нею як джерелом тваринного білка. Ї̈і висока харчова цінність обумовлена значним вмістом білків, мінеральних солей, ферментів, вітамінів, цукру, лецитину та інших речовин. За вмістом білка кров майже не відрізняється від м'яса. Цільна кров та іiі фракції містять більшість незамінних амінокислот подібно до м'яса (Pasichnyy et al., 2004; Smil, 2002).

В Україні є попит на м’ясні консервовані продукти тривалого зберігання, за даними Держкомстату (Derzhavna sluzhba statystyky Ukrainy).

\section{Таблиця 1}

Споживання м’ясних консервів в Україні за 2014-2017 pp. (Derzhavna sluzhba statystyky Ukrainy)

\begin{tabular}{ccccc}
\hline 2012 p. & 2013 p. & $2014 \mathrm{p}$. & $2015 \mathrm{p}$. & $2016 \mathrm{p}$. \\
\hline 324006 туб & 486188 туб & 252187,5 туб & 276387,8 туб & 324937,7 туб \\
\hline
\end{tabular}

Це створює передумови проведення пошукових досліджень 3 розширення асортименту продуктів тривалого зберігання з високими споживчими показниками та збалансованим складом білків і жирів, зокрема при виробництві пастеризованих сосисок (Ilea, 2009; Winkelmayer et al., 2011; Wittenberg, 2012).

Відповідно до мети досліджень було розроблено рецептури сосисок на основі м'яса курчат-бройлерів 3 використанням сухої молочної сироватки, колагеновмісного препарату на основі шкури свиней Скан Про і мікронізованої харчової целюлози з визначеним рівнем гідратації, жирової емульсії на основі курячої шкури і колагеновмісного препарату Скан Про та харчової крові. За основу для виробництва пастеризованих сосисок була використана технологія сосисок варених 3 подальшим тепловим оброблянням шляхом пастеризації і стерилізації для забезпечення подовже- ного терміну зберігання (Steinfeld, 2006). Для підвищення органолептичних показників сосисок процес пастеризації і стерилізації проводили в герметично закритій тарі з використанням соусів. Рецептури запатентовано патентом України на корисну модель (Khorunzha et al., 2018).

\section{Матеріал і методи досліджень}

В процесі досліджень вивчались показники сосисок 3 різним типом теплового оброблення згідно 3 модельними рецептурами як контроль використовували сосиски “Молочні” за стандартною рецептурою, виготовлені за стандартною технологією для варених ковбасних виробів. Для модельних сосисок проведено визначення фізико-хімічних, органолептичних та мікробіологічних показників. 
Визначення концентрації іонів водню проводили на $\mathrm{pH}$-метрі-340 в водяній і сольовому витяжки використовували з модулем гідратації 1:10 при 30-ти хвилинному екстрагуванні.

В процесі досліджень визначали загальний вміст мікроорганізмів і наявність бактерій групи кишкової палички.

Відбір точкових проб для бактеріологічного аналізу проводили згідно ГОСТ 26669-85.

Суть методу визначення загальної кількості мікробів в 1 г продукту полягає в здатності мезофільних аеробних і факультативних анаеробних мікроорганізмів рости на живильному середовищі “агар” при температурі $37+5^{\circ} \mathrm{C}$ з утворенням колоній, видимих при п'ятикратному збільшенні.

Мікробіологічні дослідження проводили шляхом приготування мазків - відбитків з поверхні і глибоких шарів продукту, посіві на живильне середовище 3 подальшим вивченням отриманої культури і підрахунком кількості мікробних тіл в 1 г продукту (ГОСТ 10444.15-94).

Так само проводили бактеріоскопічне дослідження, для якого проби відбирали $з$ поверхні і зсередини продукту (Pasichnyi et al., 2017).

Амінокислотний склад продукту визначали розрахунковим методом за допомогою прикладної програми BIO1.bas, розробленої на кафедрі технології м'яса i м'ясних продуктів НУХТ. 3 використанням програми був змодельований хімічний склад модельних сосисок і показники щодо вмісту незамінних амінокислот.

Модельні рецептури сосисок, що досліджувались, наведені в табл. 2.

Таблиця 2

Рецептури модельних сосисок

\begin{tabular}{lccc}
\hline \multicolumn{1}{c}{ Складові рецептури } & \multicolumn{3}{c}{ Склад рецептури } \\
\cline { 2 - 4 } & Основна сировина, $\%$ & Рецептура 3 \\
\hline Червоне м'ясо курчат-бройлерів & 60,0 & 70,0 & 50,0 \\
Суха молочна сироватка & 10,0 & 5,0 & 5,0 \\
Скан Про (гідратація 1:5) & 20,0 & 10,0 & 5,0 \\
Кров харчова свиняча & 3,0 & 3,0 & 3,0 \\
Свинина напівжирна & - & - & 20,0 \\
Жирова емульсія (куряча шкірка) & 5,0 & 10,0 & 15.0 \\
Мікронізована целюлоза & 2,0 & 2,0 & 2,0 \\
\hline \multicolumn{2}{l}{ Сіль кухонна } & Допоміжна сировина, г на 100 кг & 2,2 \\
Емулін & 2,2 & 2,2 & 1,0 \\
Перець чорний мелений & 1,0 & 1,0 & 0,1 \\
\hline
\end{tabular}

Для визначення впливу теплового обробляння свіжовиготовлені в лабораторних умовах сосиски герметично пакували в скляну тару з додаванням заливних соусів і проводили пастеризацію при температурі $95^{\circ} \mathrm{C}$ за формулою (25-120-20) хв, де 25 - час на нагрівання зразків до температури пастеризації, 120 - час термостатування при заданій температурі та 20 - час охолодження.

Як соуси застосовували соус з використанням желеутворюючих згущувачів на основі харчових гідро- колоїдів (вода - 98\%, загущувач - 1\% желатин, сіль $1 \%)$.

\section{Результати та їх обговорення}

На першому етапі досліджували зміну технологічних показників желе і сосисок з різними умовами теплової обробки - сосиски варені і такі, що піддавались після варіння пастеризації, в табл. 3. наведено значення буферної ємності желе та виготовлених сосисок.

Таблиця 3

Значення буферної ємності желе після пастеризації (25-120-30)

\begin{tabular}{ccccc}
\hline Зразок & Желе пастеризоване & $\begin{array}{c}\text { Сосиски варені до } \\
\text { пастеризації }\end{array}$ & $\begin{array}{c}\text { Сосиски “Молочні” } \\
\text { (контроль) }\end{array}$ & $\begin{array}{c}\text { Сосиски } \\
\text { пастеризовані }\end{array}$ \\
\hline $\mathrm{pH}_{0}$ желе & 6,75 & 6,4 & 6,6 & 6,5 \\
$\mathrm{pH}_{0,005}$ & 6,3 & 5,8 & 5,8 & 6,3 \\
$\mathrm{pH}_{0,01}$ & 6,6 & 5,4 & 5,7 & 6,05 \\
$\mathrm{pH}_{0,02}$ & 6,0 & 5,3 & 5,45 & 5,7 \\
$\mathrm{pH}_{0,04}$ & 4,95 & 4,8 & 5,05 & 4,90 \\
$\mathrm{pH}_{0,06}$ & 4,85 & 4,2 & 4,9 & 4,85 \\
$\Delta \mathrm{pH}_{0 / 0,04}$ & 1,8 & 1,6 & 0,95 & 1,6 \\
$\Delta \mathrm{pH}_{0 / 0,06}$ & 1,9 & 2,2 & 1,7 & 1,65 \\
\hline
\end{tabular}

Виготовлення сосисок пастеризованих складається 3 таких технологічних операцій: розморожування та подрібнення м'яса, соління м'яса і підготовка складових рецептури; складання фаршу, наповнення обо- 
лонок фаршем, формування виробів; теплове обробляння; охолодження; підготовка банок; порціювання і заливка соусом, закатування банок; пастеризація; охолодження.

Для визначення біологічної цінності розроблених сосисок за допомогою прикладної програми BIO1.bas був змодельований хімічний склад сосисок з урахуванням їх функціонально-технологічних показників. Розроблені моделі хімічного складу сосисок пастеризованих подано в табл. 4.

\section{Таблиця 4}

Змодельований амінокислотний склад сосисок

\begin{tabular}{|c|c|c|c|c|}
\hline \multirow{2}{*}{ № } & \multirow{2}{*}{ Елемент } & \multicolumn{3}{|c|}{ Значення за хімічним складом } \\
\hline & & Рецептура № 1 & Рецептура № 2 & Рецептура № 3 \\
\hline 1 & Вміст білка в 100 г продукту, \% & 17,3 & 12,36 & 15,36 \\
\hline 2 & Загальний вміст вологи, \% & 71,0 & 73,0 & 65,0 \\
\hline \multicolumn{5}{|c|}{ Значення СКОР, по загальному вмісту в 1 г білка продукту, \% } \\
\hline 3 & Валіну & 82.03 & 86.68 & 91.34 \\
\hline 4 & Ізолейцину & 78.63 & 81.07 & 88.19 \\
\hline 5 & Лейцину & 93.66 & 97.18 & 98.18 \\
\hline 6 & Лізину & 127.49 & 137.87 & 137.75 \\
\hline 7 & Метіоніну & 87.65 & 94.35 & 93.0 \\
\hline 8 & Треоніну & 85.07 & 90.63 & 91.25 \\
\hline 9 & Триптофану & 117.79 & 128.13 & 122.68 \\
\hline 10 & Фенілаланіну & 105.28 & 109.30 & 111.53 \\
\hline 11 & Метіонін + цистин & 83.83 & 89.78 & 90.4 \\
\hline 12 & Фенілаланін + тирозин & 104.25 & 107.39 & 109.33 \\
\hline
\end{tabular}

Як видно 3 даних табл. 4, вищий рівень збалансованості за амінокислотним складом має рецептура № 3 .

Це вказує на необхідність для підвищення якісного складу сосисок пастеризованих поєднання в рецептуpax м'яса курчат-бройлерів зі свининою напівжир- ною, харчовою кров'ю і сухою молочною сироваткою.

Було досліджено мікробіологічні показники сосисок пастеризованих для рецептури № 1 та № 2 при режимах теплової обробки 20-90-20/90. Результати досліджень наведено в таблиці 5.

\section{Таблиця 5}

Мікробіологічні показники сосисок пастеризованих, для рецептури № 1 та № 2. Режими теплової обробки 25$120-20 / 95$

\begin{tabular}{ccccc}
\hline Дослідний зразок & МАФАМ, КУО/г & БГКП в 1,0 Г & Пліснява, КУО/г & Дріжджі, КУО/Г \\
\hline Сосиски, рецептура № 1 & $5,0 \times 10^{1}$ & Не виявлено & $<10$ \\
Сосиски, Рецептура № 2 & $1,5 \times 10^{2}$ & Не виявлено & $<10$ \\
\hline
\end{tabular}

Для визначення якісних відмінностей розробленого продукту органолептичну оцінку доцільно доповнити побудовою профілограм.

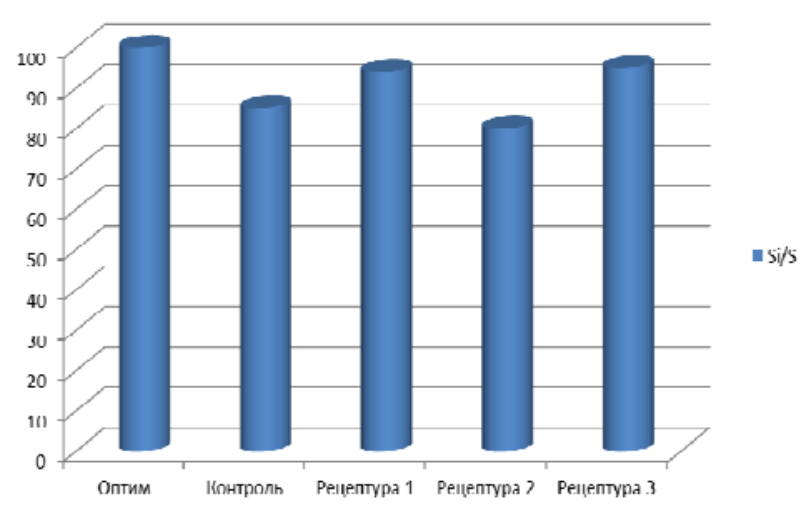

Рис. 1. Відношення площ дослідних зразків до оптимальної

Підрахувавши площі оптимального та дослідних зразків, можна помітити їх збільшення у рецептурах
№ 1 та № 2 порівняно 3 контрольним зразком та рецептурою № 3. Профілограми даних рецептур мають майже однакові площі, тому можна стверджувати про ïх високі показники якості, проте найбільше до оптимального значення наближається рецептура № 2, що наочно продемонстровано на рисунку 1.

\section{Висновки}

Сосиски 3 підвищеним вмістом гемового заліза 3 різним ступенем теплової обробки $є$ біологічно повноцінним харчовим продуктом з високими органолептичними показниками, мікробіологічні показники в межах норми.

Для підвищення рівня збалансованості сосисок пастеризованих за біологічною $\mathrm{i}$ харчовою цінністю ефективним $\epsilon$ включення до рецептур сосисок на основі м'яса курчат-бройлерів білкових поліпшувачів на основі молочної сироватки і одного 3 основних видів м'яса, а також введення до рецептур харчової крові для підвищення сенсорних показників готових до споживання виробів. 
Перспективи подальших досліджень. В подальшому планується розробити нові соуси та заливки для продукту. Також планується використання різних видів упаковки для подовження терміну зберігання сосисок.

\section{References}

Ivanov, S., Pasichniy, V., Strashinskiy, I., Marinin, A., Fursik, O., \& Krepak, V. (2014). Polufabrikatu iz miasa indeiki $\mathrm{s}$ ispolzovaniem teksturoformiryushih napolniteley. Khimiya i tekhnologiya pishchi, 48, 25-33 (in Russian).

Khorunzha, T.O., Pasechnyy, V.M., \& Logvinenko, N.P. (2017). Sosiski pasterizovaniz povyshennym soderzhaniyem gemovogo zheleza. Zhurnal Agrarnyye nauki i tekhnologii VNAU, 5(99), 155-161 (in Ukrainian).

Howe, P., Meyer, B., Record, S., \& Baghurst, K. (2006). Dietary intake of long-chain omega-3 polyunsaturated fatty acids: contribution of meat sources. Nutrition, 22(1), 47-53. doi: 10.1016.j.nut.2005.05.0099.

Wood, J.D., Enser, M., Fisher, A.V., Nute, G.R., Sheard, P.R., Richardson, R.I., Hughes, S.I., \& Whittington, F.M. (2008). Fat deposition, fatty acid composition and meat quality: A review. Meat Science, 78(4), 343-358. doi: 10.1016.j.meatsci.2007.07.019.

Pasichnyy, V.M., Kremeshna, I.V., Sabadash, P.M., Zhuk, I.Z., \& Usatyuk, S.I. (2004). Zastosuvannya krovi yak kol'oroformuyuchoyi dobavky. Naukovyy visnyk L'vivs'koyi derzhavnoyi akademiyi veterynarnoyi akademiyi im. S.Z. Hzhyts'koho, 6(3), 119-123 (in Ukrainian).

Derzhavna sluzhba statystyky Ukrainy. Ukrstat.gov.ua (in Ukrainian).

Lee, J.J. (2011). Sterilization effects of avian influenza virus and newcastle disease virus in chicken muscle and organs dependent on autoclaving time. Korean Journal of Veterinary Public Health, 2011. http://lib.rda.go.kr/newlib/adlib_en/index.html.

Nawar, W.W. (1996). Lipids. In Food Chemistry, 3rd ed.; Fennema, O.R., Ed; Marcel Dekker, Inc.: New York, 225-319.
Griffith, W.P., \& Kaltashov, I.A. (2003). Highly asymmetric interactions between globin chains during hemoglobin assembly revealed by electrospray ionization mass spectrometry. Biochemistry, 42(33), 10032-10033. doi: 10.1021/bi034035y.

Fayvishevskiy, M.L. (2006). Netraditsionnyye tekhnologii pererabotki i ispol'zovaniya pishchevoy krovi uboynykh zhivotnykh. Vse o myase, 1, 14-17 (in Russian).

Nohr, D., \& Biesalski, H.K. (2007). 'Mealthy' food: meat as a healthy and valuable source of micronutrients. Animal, 1(02), 309-316. doi: 10.1017/S1751731107657796.

Cravens, W.W. (1981). Plants and Animals as Protein Sources. Journal of Animal Science, 53(3), 817-826.

Smil, V. (2002). Eating Meat: Evolution, Patterns, and Consequences. Population and Development Review, 28(4), 599-639. doi: 10.1111/j.17284457.2002.00599.x.

Winkelmayer, R., Paulsen, P., \& Binder, R. (2011). Ethische und ökologischeAspekte der Gewinnung von LebensmittelntierischerHerkunft, Teil 1: Ethik und Evolutionsbiologie. Fleischwirtschaft, 91(6), 102-104.

Steinfeld, H. (2006). Livestock's long shadow: Environmental Issues and Options. Food and Agriculture Organization of the United Nations (FAO).

Wittenberg, K. (2012). Meat and the Enviroment - Future directions. in 58th International Congress of Meat Science and Technology. Montreal, Canada.

Ilea, R. (2009). Intensive Livestock Farming: Global Trends, Increased Environmental Concerns, and Ethical Solutions. Journal of Agricultural and Environmental Ethics, 22(2), 153-167. doi: 10.1007/s10806-008-9136-3.

Khorunzha, T.O., Pasichnyy, V.M., Kostyshyn, V.D., Pasichna, S.P., Ramik, O.S., Kharpachov, O.V. (2018). Sosysky konservovani. Patent Ukrayiny № 122445 (in Ukrainian).

Pasichnyi, V., Ukrainets, A., Shvedyuk, D., Al-Hashimi Haider Muhamed, \& Matsuk, Yu. (2017). Optimization of the canned poultry meat sterilization formula with hydrocolloids. Eastern European Journal of Enterprise Technologies, 4, 11(88), 29-34. doi: 10.15587/1729-4061.2017.108665 (in Ukrainian). 